\title{
Through the Looking Glass: Young People, Work and the Transition between Education and Employment in a post-Brexit UK
}

\section{MARION ELLISON}

Queen Margaret University, Mussleburgh, Edinburgh EH216UU, Scotland, United Kingdom, email: mellison@qmu.ac.uk

\begin{abstract}
The prospect of a profound transformation in the relationship between the UK and the European Union has raised a range of economic, social and political concerns (Dhingra et al., 2016; Booth et al., 2015; Irwin, 2015; Ebell and Warren, 2016). Whilst the ultimate shape of a negotiated post-Brexit settlement is uncertain, the potential loss or reduction in access to EU funding streams, educational mobility, EU labour market access, and changes to employment rights and regulations will impact significantly upon young people across the UK. Underlining this, the transition between education and employment has been evidenced as a period when young people experience increased risk of poverty and social exclusion (MacDonald, 2011; Furlong and Cartmel, 2004; Ellison, 2014; ILO, 2016). This article provides an analysis of the role of EU funding streams and operational programmes directed at young people's transitions between education and employment across the UK. The co-ordinated use of EU funding instruments aimed at rebalancing economic and social inequalities between wealthier and poorer regions and groups within the $\mathrm{EU}$ is evidenced as improving labour market outcomes for young people living in the most disadvantaged regions of the UK. In light of this, the article contends that future post-Brexit UK governments will need to develop redistributive investment strategies within coherent policy architectures and inclusive forms of governance to ensure the continued delivery of operational programmes for young people which are relevant, effective and sustainable at a local level.
\end{abstract}

\section{Introduction}

As a growing body of evidence reveals, a post-Brexit Europe will have significant implications for economies, labour markets and societies across Europe (Irwin, 2015; Dhingra et al., 2016; Booth et al., 2015). Whilst the economic, political and social consequences of transformations in the relationship between the UK and the rest of Europe are complex and uncertain, the population of the UK will undoubtedly experience the most profound impact of a post-Brexit settlement. The economic risks associated with the UK's exit from the EU are set out in stark relief by Dhingra et al. (2016). 
Although it is always hard to assess what the economic future may bring and there are many uncertainties, we consistently find that by reducing trade, Brexit would lower UK living standards.(Dhingra et al., 2016: 4)

Countering this argument the UK government has offered a more positive prognosis arguing that Brexit will enable the UK to secure bilateral trade deals with a broader range of nations outside the EU realising greater value to the UK economy within a two-year period. (Davis, 2016). Further, the UK will be able to secure tariff-free access to the EU single market as this arrangement would be in the mutual interest of the EU and the UK. (Davis, 2016, ibid.) In a recent White Paper (2017), the UK government has also argued that there will be greater potential for control of inward investment following the repatriation of funding from the EU to the UK.

8.51 Once we have left the EU, decisions on how taxpayers' money will be spent will be made in the UK. As we will no longer be members of the Single Market, we will not be required to make vast contributions to the EU budget. There may be European programs in which we might want to participate. If so, it is reasonable that we should make an appropriate contribution. But this will be a decision for the UK as we negotiate the new arrangements. (UK Government (2017): White paper on the United Kingdom's exit from and new partnership with the European Union: 5 )

The potential economic benefits of the repatriation of funding from the EU to the UK have been contested by a number of economists and financial analysts. (McIver and Wakefield, 2016; Ottaviano et al., 2014; Oxford Economics, 2016). A central area of concern is that the UK will no longer have access to the European Investment Bank (EIB) which has provided substantial loans for UK infrastructure projects since 1973 in sectors such as education, housing, health, transport and energy. The EIB is the largest multi-lateral lending institution. EU member states are shareholders in the EIB which delivers long-term loans on a non-profit basis to member states. In 2015 the EIB invested $€ 8$ bn in the UK including $€ 700$ million for social housing in Northern Ireland and London and $€ 400$ million for the development of the ports of Aberdeen and Liverpool. The longer-term impacts of the repatriation of funding to the UK economy and public infrastructure are thus reliant on the capacity of current and future UK governments to develop coherent and sustainable policy and investment strategies.

Critically, the current UK government argues that Brexit will also allow greater scope to build upon and modernise employment conditions and workers' rights in a 'changing labour market' (UK Government, 2017).

We are committed to maintaining our status as a global leader on workers' rights and will make sure legal protection for workers keeps pace with the changing labour market. Specifically, an independent review of employment practices in the modern economy is now underway. The 
review will consider how employment rules need to change in order to keep pace with modern business models, such as: the rapid recent growth in self-employment; the shift in business practice from hiring to contracting; the rising use of non-standard contract forms and the emergence of new business models such as on-demand platforms. (UK Government, 2017, ibid: White paper on the United Kingdom's exit from and new partnership with the European Union: 27)

Here the focus is on modern business models leading transformations in employment rules and regulations rather than employment rules, regulations and rights determining the shape of modern business models. This increased emphasis on prioritizing the needs of the market ('modern' economy) and 'modern' business models strongly implies a market-led post-Brexit political economy in the UK. Here the proposed shift from publically driven to marketdriven policy strategies is brought into sharp relief. The potential impact of this shift on vulnerable groups in the UK labour market is a central concern. Demonstrating this, non-standard contracts affect young people aged between 18 and 25 more than any other age group and young people hold over onethird of all zero-hour contracts in the UK labour market (ONS, 2017; Otto and Taylor-Gooby, 2014).

The potential consequences of a post-Brexit settlement for work and welfare in the UK are of central concern particularly for vulnerable groups. Highlighting this, recent research has evidenced the disproportionate impact of economic uncertainty upon young people in the UK and across all European labour markets (Tinson et al., 2016; ILO, 2015; Otto and Taylor-Gooby, 2014). Young adults are now one of the most vulnerable groups across European societies and beyond particularly in terms of poverty and social exclusion and the labour market (Eurostat, 2017; ONS, 2017; Scottish Government, 2015; ILO, 2015). In the UK this vulnerability has been compounded by societal risks, including the marketisation of Higher Education in England and Wales, the imposition of work and welfare reforms with high degrees of conditionality and flexible labour market conditions. The latter are characterised by a high proportion of part-time, temporary and zero-hour contracts contributing to fragmented and incoherent youth transitions between education and employment (Tinson et al., 2016; Ellison, 2014; MacDonald, 2011; Furlong and Cartmel, 2004). Moreover, the loss of those EU funding streams directed at specific policy programmes for young people is particularly concerning as these innovative policies and measures have been evidenced as supporting and sustaining youth transitions between education and employment (Ellison and Fenger, 2013; Ellison and Van Berkel, 2014). Moreover, the loss of the redistributive capacity of the European Social Fund (ESF) and the European Regional Development Fund (ERDF) to regional and local investment in the UK will exacerbate spatial inequalities unless future UK governments implement policy instruments based upon a more redistributive fiscal and investment regime. 
With a focus upon the direct and indirect consequences of a post-Brexit Europe on key areas including the future of broader EU funding streams, trade rules, movement of labour, employment rights and regulations and educational mobility, this article argues that the broader economic and societal risks of a postBrexit settlement may well have significant negative consequences for vulnerable young people's experience of work and the transition between education and employment in the UK. The article is informed by major research undertaken for the $\mathrm{EU}\left(\mathrm{FP}_{7}\right)$ INSPIRES project (2013 to 2016).

\section{The political economy and governance of youth transitions in the UK and Europe}

For many young people across Europe the journey between education and employment is impeded by contours of economic, spatial, social, educational, and health inequalities. (IPPR, 2017; European Commission, 2014; OECD, 2013; ILO, 2016; Tinson et al., 2016) The complex and multi-dimensional vulnerabilities resulting from these conditions in the UK are well documented (MacDonald, 2011; Roberts, 2011; Thompson, 2011; Furlong and Cartmel, 2004; Ellison, 2014).

Demonstrating this, the deregulation of the labour market in the UK has led to an increase in non-standard employment including an exponential rise in zero-hour contracts, from 747,000 in 2015 to 903,000 in 2016: a 20 per cent increase. Critically, 36 per cent of all zero-hour contracts were held by young people aged between 16 and 24 in 2016 (ONS, 2017; ONS, 2014; Gardiner, 2014). Recent studies have highlighted the long-term impact of poor job quality and insecure conditions on the social and psychological well-being of young people (Elliot, 2016; The Princes Trust, 2014; Ellison, 2014; Lindsay and Houston, 2011).

In the UK austerity measures have also led to lower levels of investment in Business, Innovation and Skills (Figure 1). The long-term failure to address the entrenched and systemic lack of investment in skills programmes, training and education has led to a situation in which young people in the UK have lower skill levels when compared to other OECD countries (OECD, 2016).

Expenditure on active labour market policies as a percentage of GDP in the UK is well below the average ratio for all 28 countries in the EU. In 2011, the most recent year for which UK data is available for comparative purposes, the UK spent only 0.23 per cent of its GDP on active labour market measures compared to 1.93 per cent in Denmark. The cumulative impact of under-investment in skills training and labour market interventions is demonstrated by the percentage of young people in the UK without basic skills (OECD, 2016). Moreover, the European Social Inclusion monitor Social Justice Index Score for Child and Youth Opportunity 2015, reveals the UK as being ranked below the EU average for, and eighteenth out of, the 28 countries surveyed (Figure 2). In the UK, 32.6 per cent of children and young people were at risk of poverty and social exclusion in 2016. 


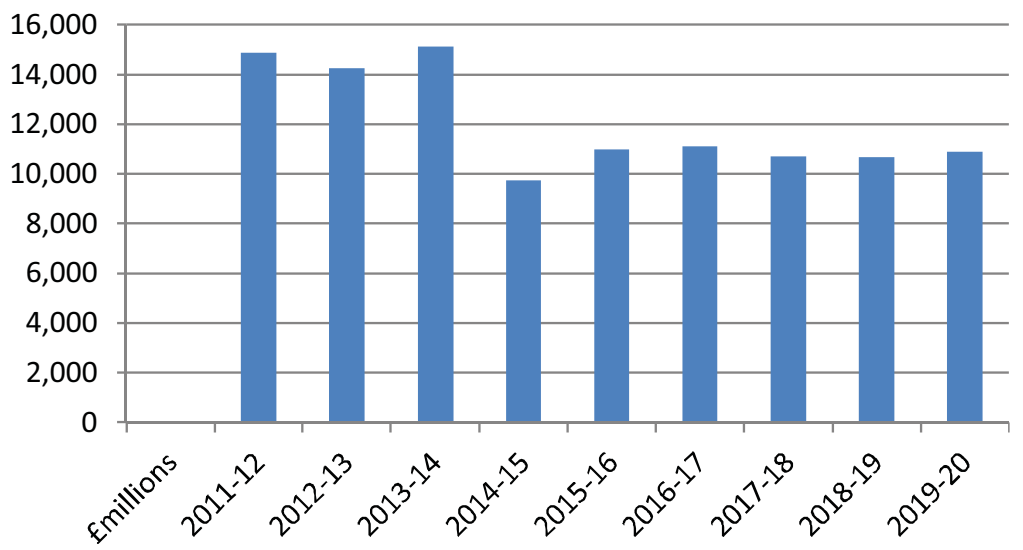

Figure 1. (Colour online) Business Innovation and Skills Source: ONS: Data Extracted $6^{\text {th }}$ January, 2017

Social Justice Index Score 2015: Child and Youth Opportunity

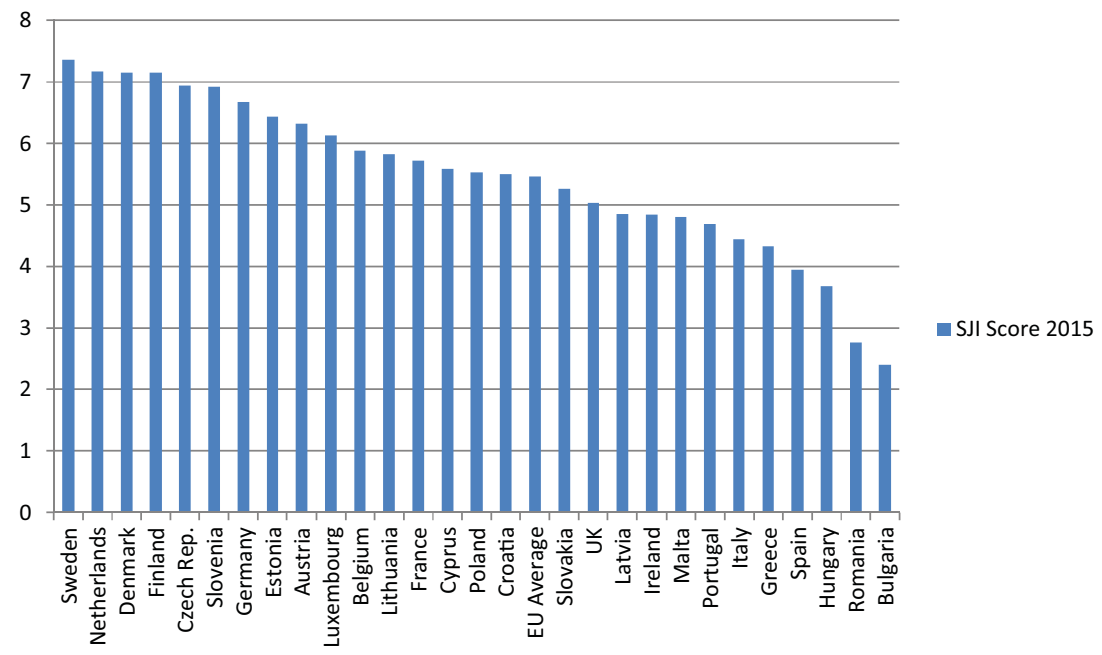

Figure 2. (Colour online) Social Justice in the EU

Source: Social Justice in the EU - Index Report 2015: Social Inclusion Monitor Europe (own calculations) Extracted 7 th January 2017.

As Figure 3 (below) reveals, between 2008 and 2016 the levels of young people who were neither in employment nor education and training were consistently higher in the UK than a number of EU countries including Germany, Czech Republic, Denmark, the Netherlands, Finland, Sweden and Norway. 


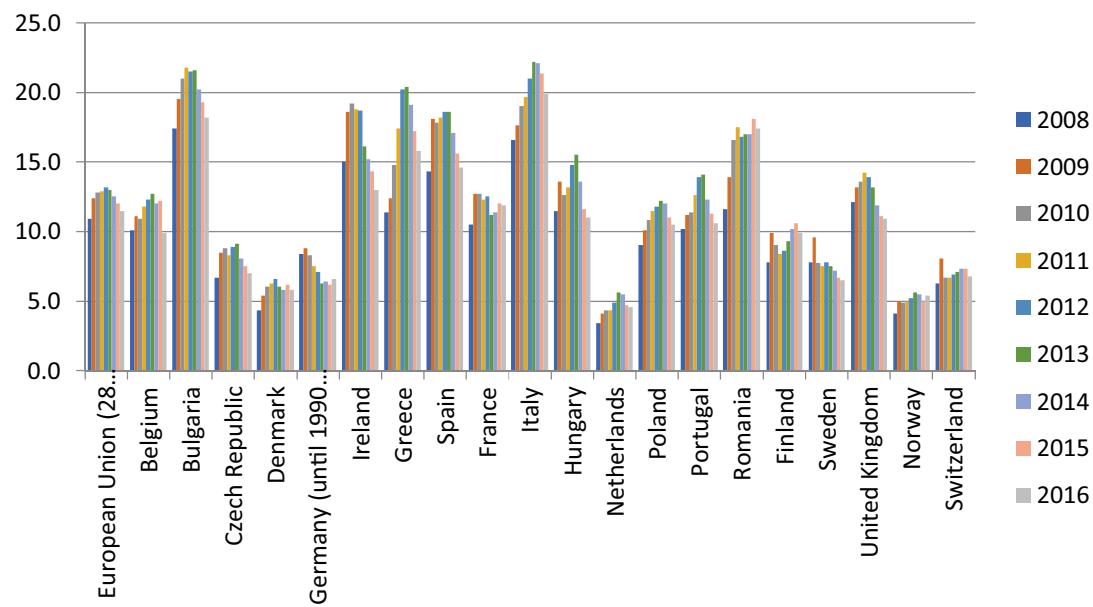

Figure 3. (Colour online) Young people neither in employment nor in education and training by sex, age and educational attainment level (NEET rates): January to April 2016

Source: Eurostat: Last update 03.05.17: Extracted on 07.05.17. Unemployed persons in neither formal nor informal education and training. All ISCED 2011 levels

\section{The impact of EU funding and policy strategies on young people's experience of work and the transition between education and employment in the UK Introduction}

Policy responses to youth unemployment at EU level have crystallized around the EU 2020 strategy Youth on the Move which focuses upon the vulnerability of young people with low levels of education and calls for sustainable integrated support measures to aid the transition from education to work within a global knowledge economy. A central policy concern for the EU Commission has been the barriers and constraints faced by young people who are neither in employment nor in education or training (NEETs) (DG Call for proposals No. VP/2012/012). In 2013, the EU launched The Youth Employment Package (YEP) including a Youth Guarantee stipulating that all young people aged up to 25 should receive a quality job offer, continued education, an apprenticeship or a traineeship within four months of leaving formal education or becoming unemployed. All member states are required to implement the Youth Employment Initiative.

\section{The impact of EU funding on the digital skills sector}

A key area of under-investment within the UK economy is the digital skills sector. A recent report issued by the UK Government during May 2015 acknowledged this major long-term failure of policy before the General Election. 'The UK is at tipping point: The country is not addressing its significant digital skills shortage and an incoming Government urgently needs to resolve this' (House 
of Lords Select Committee on Digital Skills, Report of Session 2015: 12). Here, a significant lack of government investment and coordination of digital initiatives led to certain sectors of society, and UK regions, falling behind at a significant cost to the UK economy. Investment in Information and Communication Technologies in the UK is heavily reliant upon EU funding and $\mathfrak{L}_{25} 6$ million was to be invested through the European Regional Development Fund (ERDF) between 2014 and 2020. The European Commission has also actively supported the development of programmes enabling young people to develop skills within the digital sector (European Commission, 2016).

\section{The redistributive function of European funding}

Between 2014 and 2020 the European Social Fund and European Regional Development Fund will invest a total of 11.8 billion across six operational programmes in the UK; England, Gibraltar, Wales, Northern Ireland and Scotland (Eurostat, 2017). The funds aim to reduce economic and social inequalities between the EU's regions, supporting economic development in poorer regions. Wales is one of the UK's poorest regions which was set to receive $€_{2.4}$ billion between 2014 and 2020, the highest level of funding of any region in the UK. In contrast, the south-east of England will receive only $€ 286$ million as it is one of the wealthiest regions of the UK. Recent impact evaluations have underlined the pivotal impact of EU structural funds in stimulating and sustaining employment in poorer regions in the UK. Here, it has been estimated that ERDF projects have created approximately 36,640 jobs in Wales, 20,149 jobs in Yorkshire and 44,311 jobs in Scotland (Hunt et al., 2016)

European Social Funding is also critical to the redistributive function of European funding. In the UK $€_{206}$ million was allocated to the Youth Employment Initiative from 2013 with the aim of addressing youth poverty and social exclusion by reducing youth unemployment and improving access to skills and training. Pivotal to YEI funding is the encouragement of investment in intermediate and higher level skills, qualifications, training and quality apprenticeships. Whilst the YEI offers targeted funding, broader funding instruments including the EU Growth and Employment Fund, the Sustainable Growth Fund, the Regional Convergence Fund and the Seventh Framework Fund have also supported the redistribution of economic and social investment in the UK contributing to more coherent and sustainable youth transitions across the UK. As Table 1 (below) illustrates, levels of EU investment across the UK increased year on year between 2011 and 2015 . Increasing levels of EU Expenditure in the UK rose from $€ 6,579$ million in 2011 to $€_{7,547.6}$ million in 2015 (Eurostat, 2017). Figure 4 illustrates the composition of this funding. The development of an effective post-Brexit investment strategy will need to take full account of the economic, social and spatial redistributive function of this investment and will need to 
Total EU Expenditure in the UK, all areas between 2011 and $2015 \mathrm{€m}$

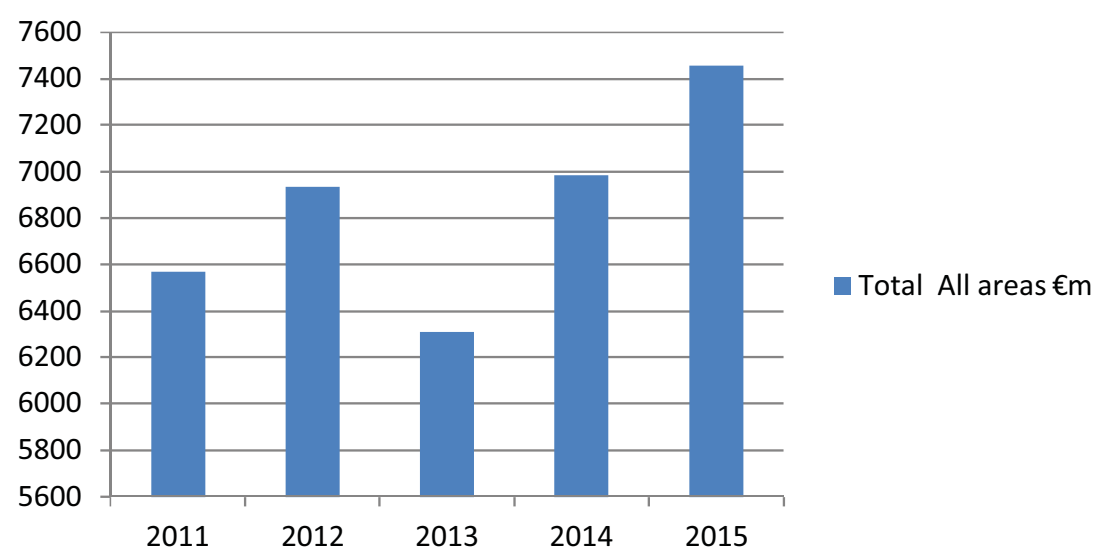

Figure 4. (Colour online) EU Expenditure within the UK between 2011 and 2015

Source: Eurostat, 2017: Figures extracted $14^{\text {th }}$ January 2017

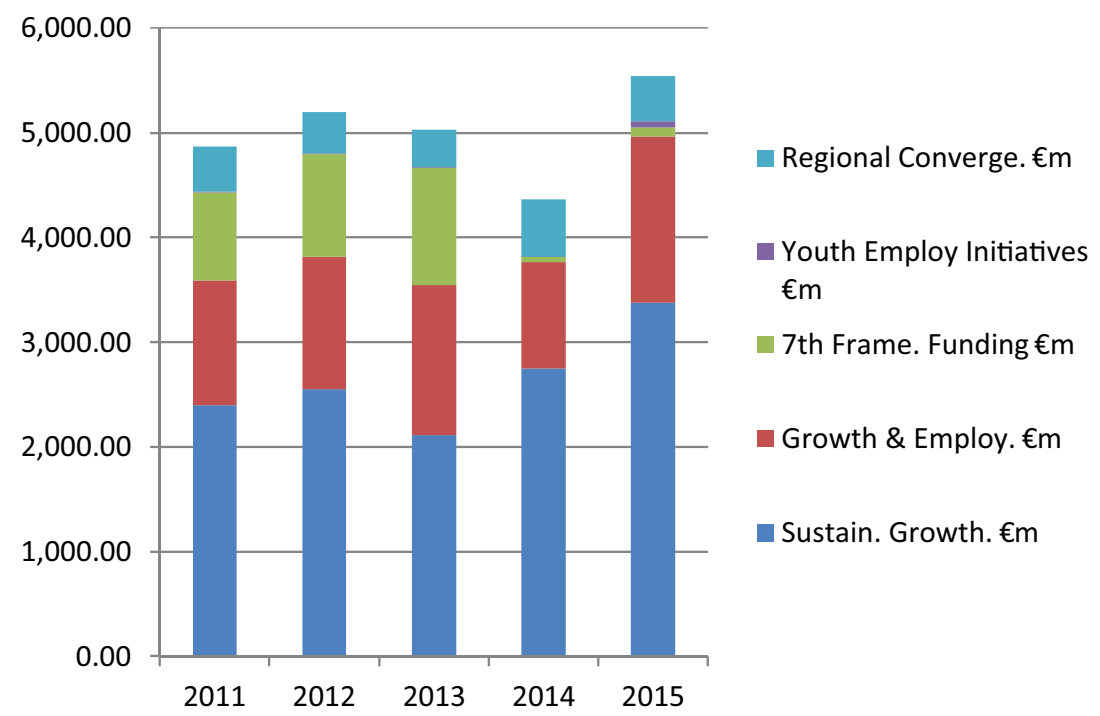

Figure 5. (Colour online) European Union Expenditure within the UK (Selected Areas of Expenditure)

Source: Eurostat, 2017; EU Expenditure and Revenue: Budget for 2014-2020: Data extracted for 2000-2015. http://ec.europa.eu/budget/figures/interactive/index_en.cfm Figures extracted 9th January, 2017 
TABLE 1. Allocation of EU Youth Employment Initiative Funding: 2014-2020

\begin{tabular}{|c|c|c|c|}
\hline $\begin{array}{l}\text { Member } \\
\text { State }\end{array}$ & $\begin{array}{l}\text { Regions eligible for extra } \\
\text { funding under the Youth } \\
\text { Employment Initiative }\end{array}$ & $\begin{array}{l}\text { Youth Employment } \\
\text { Initiative specific } \\
\text { allocation }(€ \text { million })^{*}\end{array}$ & $\begin{array}{l}\text { Youth Employment } \\
\text { Initiative specific } \\
\text { allocation }(€ \text { million, } \\
\text { current prices)* }\end{array}$ \\
\hline Belgium & Yes & 39.64 & 42.44 \\
\hline Bulgaria & Yes & 51.56 & 55.19 \\
\hline $\begin{array}{l}\text { Czech } \\
\text { Republic }\end{array}$ & Yes & 12.71 & 13.60 \\
\hline Denmark & No & - & - \\
\hline Germany & No & - & - \\
\hline Estonia & No & - & - \\
\hline Ireland & Yes & 63.66 & 68.14 \\
\hline Greece & Yes & 160.24 & 171.52 \\
\hline Spain & Yes & 881.44 & 943.50 \\
\hline France & Yes & 289.76 & 310.16 \\
\hline Croatia & Yes & 61.82 & 66.18 \\
\hline Italy & Yes & 530.18 & 567.51 \\
\hline Cyprus & Yes & 10.81 & 11.57 \\
\hline Latvia & Yes & 27.10 & 29.01 \\
\hline Lithuania & Yes & 29.69 & 31.78 \\
\hline Luxembourg & No & - & - \\
\hline Hungary & Yes & 46.49 & 49.77 \\
\hline Malta & No & - & - \\
\hline Netherlands & No & - & - \\
\hline Austria & No & - & - \\
\hline Poland & Yes & 235.83 & 252.44 \\
\hline Portugal & Yes & 150.20 & 160.77 \\
\hline Romania & Yes & 99.02 & 105.99 \\
\hline Slovenia & Yes & 8.61 & 9.21 \\
\hline Slovakia & Yes & 67.43 & 72.17 \\
\hline Finland & No & - & - \\
\hline Sweden & Yes & 41.26 & 44.16 \\
\hline $\begin{array}{l}\text { United } \\
\text { Kingdom }\end{array}$ & Yes & 192.54 & 206.10 \\
\hline Total & & 3000 & 3211 \\
\hline
\end{tabular}

Source: EU Commission, $2014{ }^{*}$ Member States have to match these amounts by at least the same amounts from their European Social Fund allocation.

provide sufficient investment to ensure the continuity of policy programmes and measures that are crucial to economic and social development across the UK.

YEI funding was introduced in 2013 to enable young people who live in areas of poverty and social exclusion to overcome some of the barriers and challenges that they encounter as they undertake the transition between education and employment. As Table 1 below shows, the UK has benefited significantly from this extra funding in comparison to many other EU countries. 
Crucially the funding gaps faced by local, regional and national governments in the UK following withdrawal from the European Union are compounded by an equally profound challenge of governance. Central principles of social partnership designed to increase the effectiveness of EC regional policies at local level have guided the implementation of ESF funding across Europe since 1988 (The EU Commission, 2014; (Schraad-Tischler, 2015) Barca, 2009;). Collaborative social partnerships between trade unions, employer organisations and other key stakeholders at local level are encouraged and indeed required by EU funding rules. Innovative and sustainable measures designed to support young people's transitions from education to employment at local level have emerged as a result of the development of collaborative social partnerships (European Commission, 2014).

\section{The redistributive role of ERDF and ESF funding in the UK}

European Regional Development and European Social Funding play a significant role in reducing economic and social inequalities between the regions of the EU. During the period 2014-2020 the UK will receive $€ 10.9$ billion in ERDF and ESF funding. Poorer regions in the UK including the north-east of England, the south-west of England, Wales and Northern Ireland receive more substantial levels of ERDF/ESF funding than wealthier regions. A primary role of ERDF funding is to stimulate local economic development (European Commission, 2010). Consolidating this, ESF-funded projects are designed to ensure that children and young people from disadvantaged regions of Europe benefit directly from increased access or enhanced access to educational, training and employment opportunities (The Official Journal of The European Union, 2013; European Commission, 2014).

\section{The south-west of England}

As a European-designated deprived region, the south-west of England benefits significantly from EU funding. Young people in the region have access to projects funded through EDRF convergence funding and ESF funding. A recent audit of ERDF/ESF performance indicators 2007-2014 for the south-west of England has underlined the positive impact of EU co-funded projects. Here, Cornwall and the Isles of Scilly have particularly benefited from EU funding when impact is considered on a per capita basis (Table 2, below)

During the current funding period 2014-2020 the south-west region has established a number of EU funded projects focusing upon education, and skills development for young people making the transition between education and employment. Additionally emphasis is being placed on enabling lower paid workers to develop their careers through skills development. Apprenticeship programmes incorporating globally recognised industry qualifications are also an important component of the portfolio of EU-funded projects in the region. 
TABLE 2. ERDF/ESF performance indicators 2007-2014: the south-west of England

\begin{tabular}{|c|c|c|}
\hline Indicator & $\begin{array}{l}\text { Cornwall and Isles } \\
\text { of Scilly }\end{array}$ & $\begin{array}{l}\text { South West } \\
\text { England }\end{array}$ \\
\hline Gross new jobs created & 4761 & 4226 \\
\hline $\begin{array}{l}\text { Number of RTD (Research, Training and Development) } \\
\text { projects supported }\end{array}$ & 10 & 19 \\
\hline Number of projects investing directly in SMEs & 68 & 9 \\
\hline Number of start-ups supported & 22 & 1294 \\
\hline Private sector investment induced ( $€$ million) & 121.5 & 22 \\
\hline
\end{tabular}

Source: South West Greenerin.org.UK

\section{The north-east of England}

Despite having the lowest GDP per capita in England, the north-east of England is not one of the poorest regions in the EU as a whole. Exceeding 75 per cent of the average GDP in the EU, it is not entitled to European Funding under the European convergence of regions objective. Under the convergence criteria, poor regions receive more than 80 per cent of ERDF funding which provides financial support to projects that stimulate regional development. The north-east of England is, however, entitled to funds designated for regional competitiveness, employment and regional development.

\section{Wales}

Wales has been a recipient of EU policy funding particularly EFSI, ERDF and ESF funding, since the creation of the National Assembly for Wales in 1999, and West Wales and the Valleys continues to be classified by the EU as a 'less developed region' being eligible for maximum levels of EU Cohesion and Structural policy investment. Between 2014 and 2020 Wales was to gain $\mathfrak{E} 1.9$ billion in structural funding. Policy programmes for young people are focused on education, training, skills and educational mobility across Europe (The Welsh Government, 2017).

\section{Northern Ireland}

In Northern Ireland close policy alignment between EU 2020 policy strategies and those of the Northern Ireland devolved administration are evidenced by an emphasis on programmes for vulnerable young people who are neither unemployed nor in education or training. Northern Ireland was to receive $€_{3.5}$ billion between 2014 and 2020 for programmes such as Belfast Works and the LEMIS. The LEMIS project delivers free skills training as part of Northern Ireland's ESF programme to combat poverty and social exclusion and increase the skills base of those currently in work. 
Concern relating to the impact of Brexit on these programmes has been voiced by a number of organisations including the CBI in Northern Ireland. The Director of the CBI in Northern Ireland has recently stated that:

Our members are very fearful of the withdrawal of EU Funding for investment and skills training (Angela MacGowan, Northern Ireland Director of the CBI: Radio Four Today Programme 10/5/2017).

Of greater concern is the impact that the constitutional challenges raised by the UK's withdrawal from the European Union will have on the peace process in Northern Ireland. Since 1995 Europe has paid $€_{1.3}$ billion to support peace in Northern Ireland and the border counties in the Republic of Ireland through the PEACE and Interreg programmes (The Northern Ireland Government Department of Economy, 2016).

\section{Scotland}

In Scotland, recent research conducted by the INSPIRES EU $\left(\mathrm{FP}_{7}\right)$ research project has evidenced the significance of EU co-funded collaborative partnerships between trade unions, employer organisations, local authorities and further and higher educational institutions in promoting more sustainable measures aimed at supporting young people as they make meaningful and coherent transitions between education and employment (Ellison, 2013).

As the case studies drawn from England, Wales, Northern Ireland and Scotland show, young people undertaking the transition between education and work in the UK benefit substantially from funding allocated by the European Commission. The redistributive function of the EU budget and direct multi-level governance arrangements between the EU and local administrations in the UK are intrinsically woven into regional development policies across the UK (OECD, 2016).

The design and implementation of a post-Brexit investment strategy will require full cognisance of these challenges. The continuity of progressive policy measures and programmes which effectively support coherent and meaningful youth transitions necessitates a commitment by the UK government to the redistribution of economic, industrial and social investment across the UK. Moreover, as previously evidenced, the effective implementation and sustainability of these programmes also requires a political commitment to progressive governance and social partnership arrangements. The evidential base presented in this article has demonstrated the positive impact of existing forms of multi-level governance and social partnership arrangements between the EU and local stakeholders in the UK. The challenge is to ensure continuity of these arrangements in order to provide young people with forms of local support, and employment opportunities to enable them to navigate the challenges and barriers 


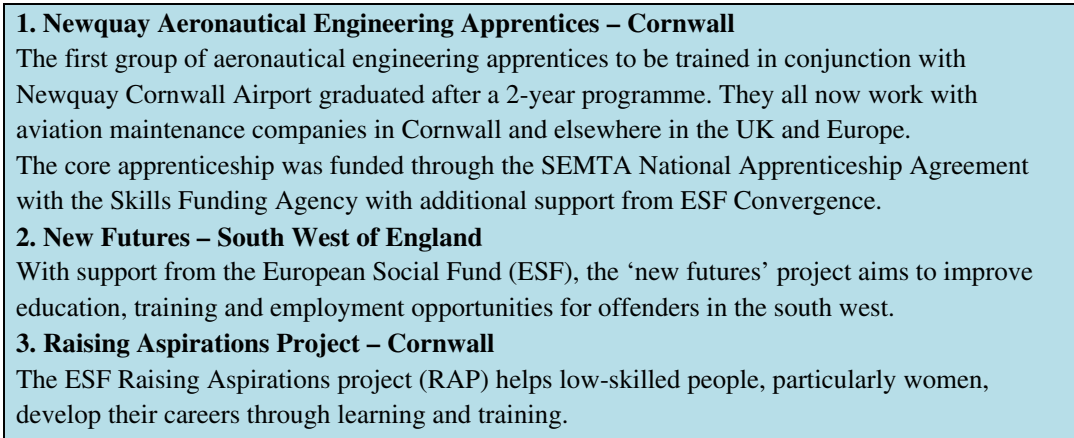

Figure 6. (Colour online) Projects aimed at facilitating education and skills development for young people in the south-west of England: 2014-2016

Source: South West Greenerin.org.uk

Between 2007 and 2014 the North East Region received $£ 195.4$ million in ESF funding and $£ 296.8$ million in ERDF
funding, a per-capita investment of $£ 73$ and $£ 114$ respectively. A central objective of ESF funding is to enable
children and young people from disadvantaged regions to gain increased access to educational, training and
employment opportunities reinforcing coherent and meaningful transitions between education and employment. This
funding is matched by co-funding organisations including The Department for Work and Pensions and the Skills
Funding Agency (SFA). Between 2007 and 2014 this region gained $£ 198.2$ million from co-funding organisations.
Projects which benefited from this investment included Gateshead College ( $£ 10,753,750$ ); New College Durham
$£ 8,557,950$; and DWP Working Links $£ 8$ million. All of these projects contribute significantly to youth transitions
between education and employment in the North East of England.

Figure 7. (Colour online) The contribution of ERDF/ESF funding to youth transitions in the north-east of England 2007-2014

Source: North East Local Enterprise Partnership (2017), http://www.nelep.co.uk/ [accessed on 619 26.02.2017]

they face in sustaining coherent and meaningful transitions between education and employment.

\section{Rebalancing regional disparities in labour market conditions for young people; the role of EU redistributive funding instruments in the UK}

Economic and industrial strategies, characterised by a concentration of public and private investment within the south of the UK, are starkly demonstrated below by changes in workforce jobs between 2015 and 2016 (Figure 6 below). Notably, both the north-west of England and Scotland experienced a reduction in workforce jobs during this period, losing 5,00o and 7,000 workforce jobs respectively, with the north-east of England, Wales and Northern Ireland experiencing small increases of between 2000 workforce jobs for the north-east of England and 8000 workforce jobs for Northern Ireland, with Wales experiencing an increase of only 6000 workforce jobs during this period.

Despite this trend, levels of youth unemployment in all five areas decreased between 2015 and 2016 with consistent downward trends in levels of youth unemployment continuing in Scotland, the north-east, the north-west and 


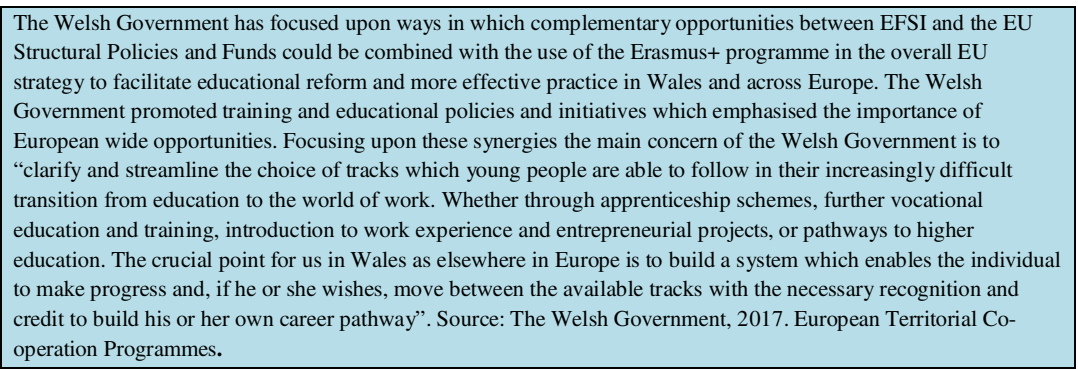

Figure 8. (Colour online) Policy strategies directed at youth transitions in Wales

The Welsh Government (2017), European Territorial Cooperation Programmes. http://gov. wales/funding/eu-funds/european-cooperation/?lang=en [accessed on 14.03.2017]

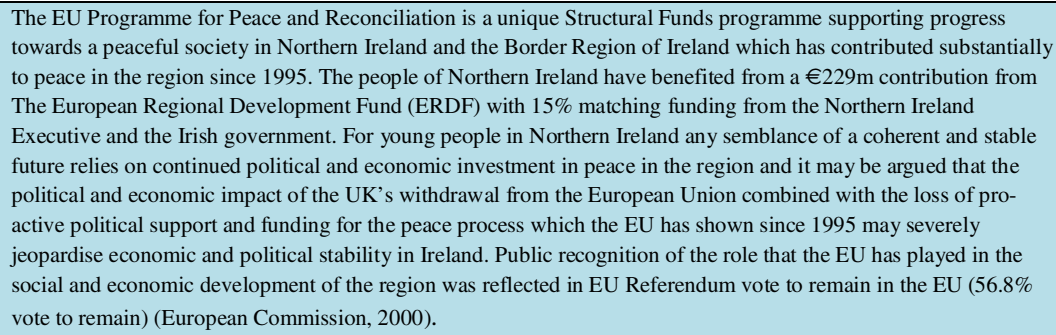

Figure 9. (Colour online) The EU programme for peace in Northern Ireland

Source: European Commission (2000), EU Programme for Peace and Reconciliation in Northern Ireland and the Border Region of Ireland 2000-2004. Operational Programme "Reinforcing Progress towards a Peaceful and Stable Society and Promoting Reconciliation" 1278, http://ec.europa.eu/regional_policy/archive/country/overmap/pdf_region/fp2mc_en.pdf [accessed 05.03.2017]

Northern Ireland. Whilst a range of factors have influenced youth employment levels, the evaluation of impacts from specific ESF/ERDF-funded projects in these areas underlines the contribution of ESF/ERDF funding in stabilizing, and indeed decreasing, levels of youth unemployment in regions which have experienced significant reductions in workforce jobs during this period. Significantly, as Figure 14 (below) reveals, four of these regions have also benefited from higher levels of per capita combined ESF and ERDF allocations when compared with other regions within the UK. Scotland's allocated levels of combined ESF and ERDF funding per capita are not as high as the other four regions being similar to levels allocated to Yorkshire and Humberside and the East Midlands. However, the current Scottish Government has demonstrated high levels of engagement with the European Commission in developing and co-funding projects, multi-level governance arrangements and delivery strategies to support multi-sectorial policies designed to reduce inequality and poverty as part of the 'Solidarity Purpose'. (Scotland Europa, 2017; Scottish Government, 2015) 
The European Skills Panorama provides data and information relating to labour markets and skills needs across Europe facilitating the development of education and training systems which are more closely aligned to labour market needs particularly with regard to knowledge-based and technological skill demand. The skills intelligence base in Scotland aims to provide a closer alignment between investment in educational and training programmesand skill demand across Europe. Regional Skills Assessments and Regional Skills Investment Plans (RSIPs) have also been developed to enable regions to formulate and develop proactive programmes and measures to meet changing skills needs at local, national, UK and European level. Demonstrating this approach the Scottish Government developed the first digital skills academy in the UK. CodeClan equips students with the knowledge and skills they need to code software. The course is accredited by the Scottish Qualifications Agency. Moreover the course is a Professional Development Award (PDA) which has gained international recognition. The Scottish Government is set to benefit from $€ 5.6$ billion in funding from the EU between 2014 and 2020 and is committed to membership of the European Union as part of its broader economic and industrial strategy. (Scottish Government 2015a and 2015b)

Figure 10. (Colour online) Scotland: Alignment with the European Skills Panorama Source: Scottish Government (2015a), Scotland's Action Plan for EU Engagement. The Scottish Government. Edinburgh. 1-14. March 27th, 2015, http://www.gov.scot/ Resource/o047/00473826.pdf. [accessed 20.02.2017] and Scottish Government (2015b), European Parliament Engagement Report on Skills Policies for Fighting Youth Unemployment. The Scottish Government, Edinburgh. http://www.gov.scot/Topics/International/Europe/ Case-Studies/YouthUnemployment [accessed 19.02.2017]

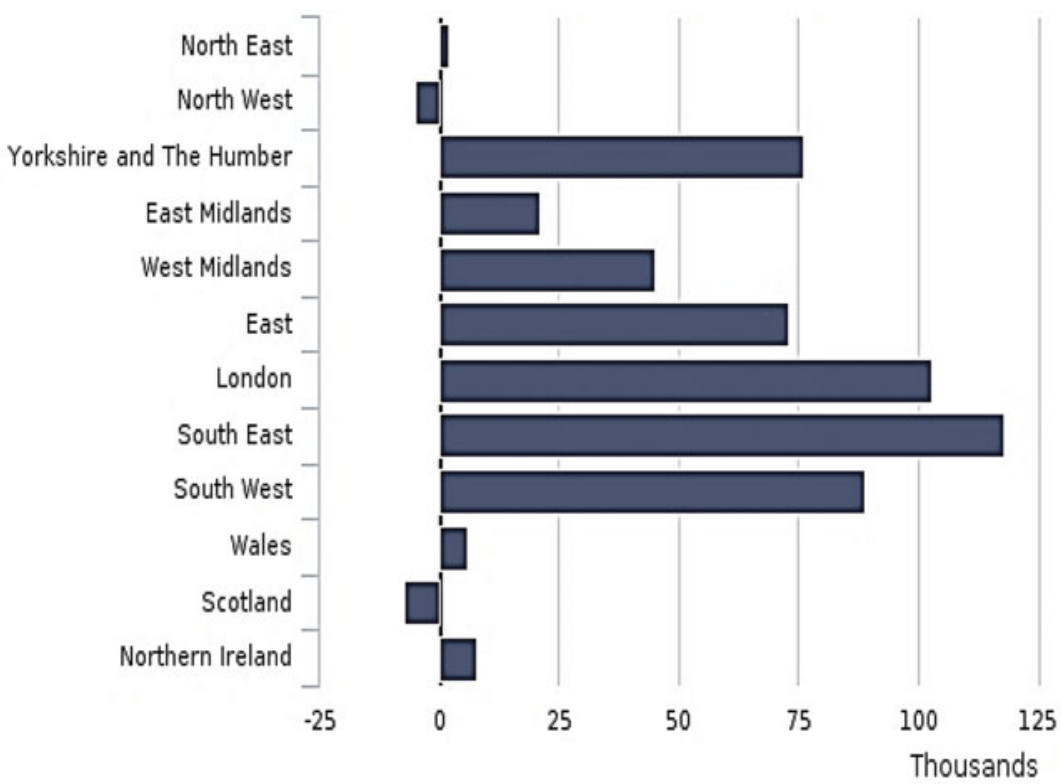

Figure 11. (Colour online) Change in workforce jobs, by region, seasonally adjusted, September 2015 and September 2016

Source: Office for National Statistics (2017), Labour Force Survey: regional labour market statistics. http://www.ons.gov.uk/ons/rel/subnational-labour/regional-labourmarket statistics/january-2014/stb-regional-labour-market-january-2014.html [accessed 06.04.2017] 


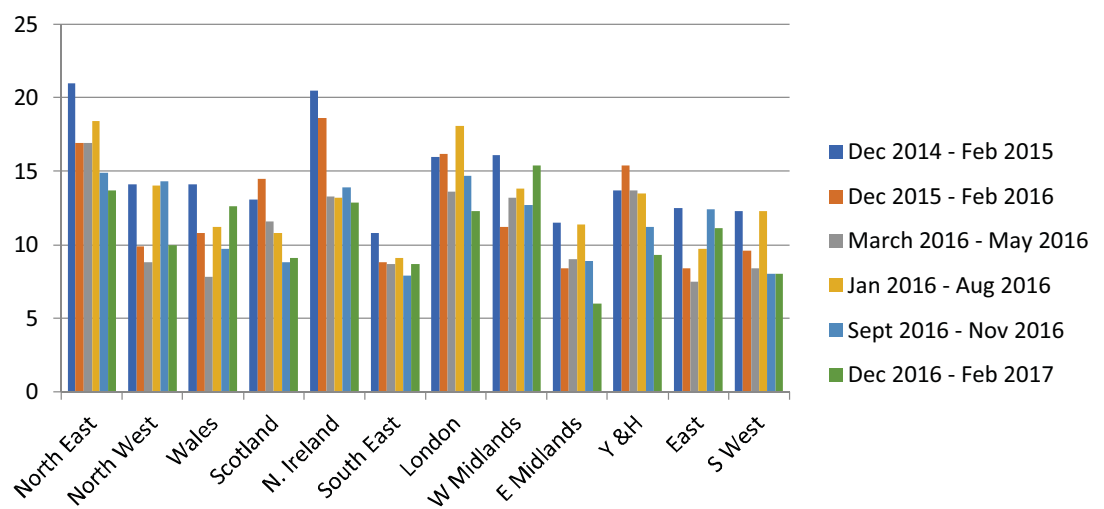

Figure 12. (Colour online) Regional unemployment by age: 18-24 years in the UK between 2014 and 2017

Source: Office for National Statistics (2017), Labour Force Survey: regional labour market statistics. line, http://www.ons.gov.uk/ons/rel/subnational-labour/regional-labour marketstatistics/january-2014/stb-regional-labour-market-january-2014.html [accessed 06.04.2017]

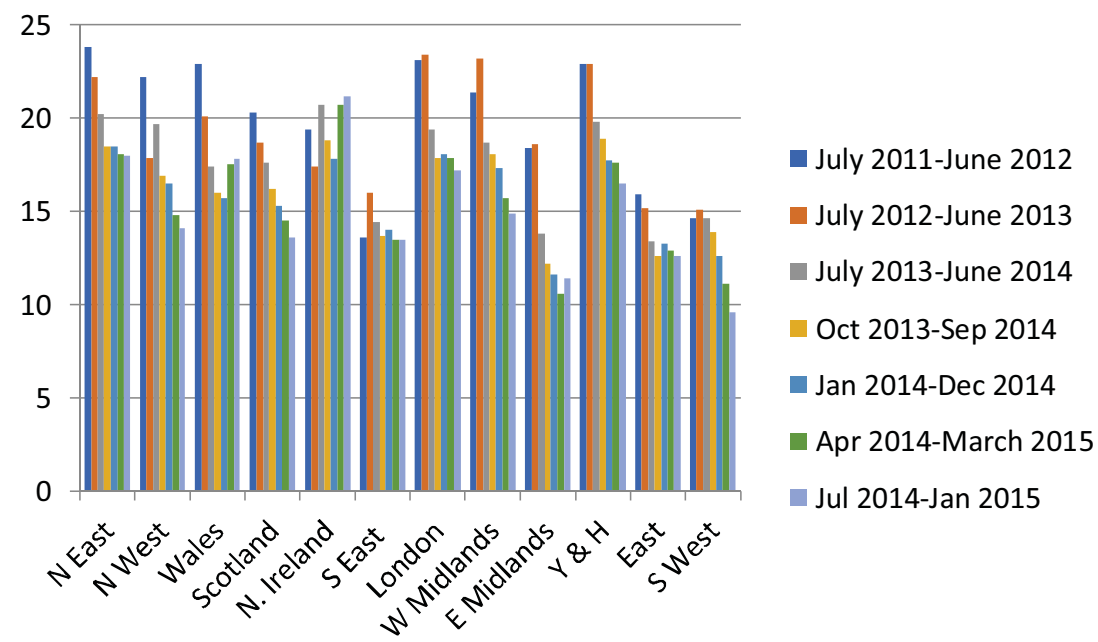

Figure 13. (Colour online) Regional unemployment by age: 18-24 years in the UK between 2011 and 2014

Source: Office for National Statistics (2017), Labour Force Survey: regional labour market statistics. line, http://www.ons.gov.uk/ons/rel/subnational-labour/regional-labour marketstatistics/january-2014/stb-regional-labour-market-january-2014.html [accessed 06.04.2017]

Significantly, London and the West Midlands both had high levels of youth unemployment between January 2016 and August 2016 despite significant growth in workforce jobs between September 2015 and September 2016. The level of youth unemployment in London between January 2016 and August 2016 was 18.1 per cent despite a substantial increase in total workforce jobs of 103,000 


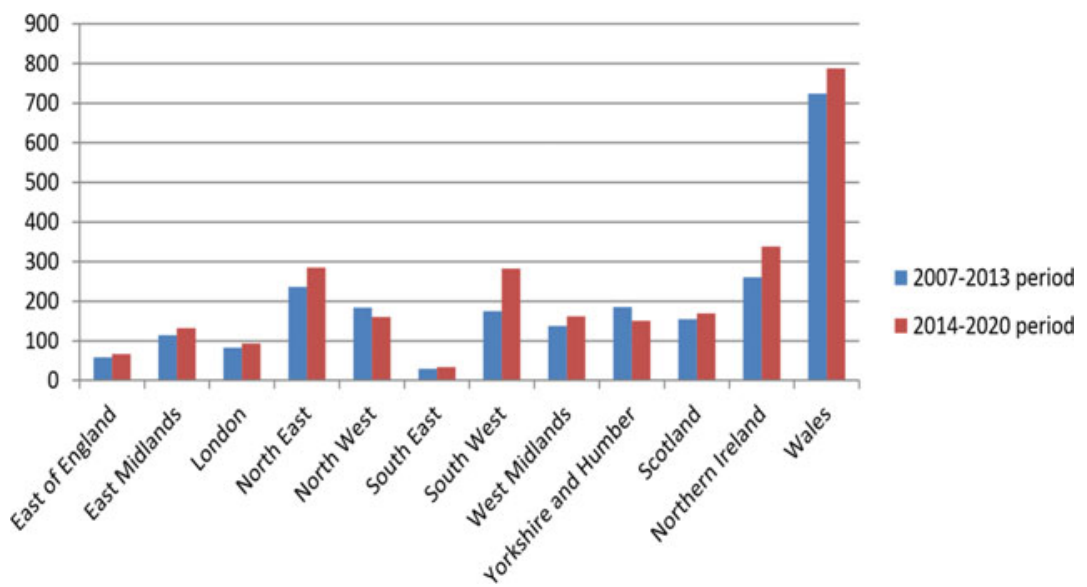

Figure 14. (Colour online) Per Capita combined ESF and ERDF allocations by region (in Euros) Source: SPERi: British Political Economy Brief. No 24: UK Regions and European Structural and Investment Funds https://www.publications.parliament.uk/pa/cm201314/cmhansrd/cm130703/ text/130703w0003.htm\#130703w0003.htm_wqn31 http://parliament.uk/business/publications/ written-questionsanswers-statements/written-question/Commons/2016-03-22/32053/

between September 2015 and September 2016 (ONS, 2017). It is significant that, at $€_{96}$ per capita between 2014 and 2020, London receives one of the lowest allocations of combined ESF and EDRF funding in the UK. Contrastingly, the level of youth unemployment in Wales between January 2016 and August 2016 was 11.0 per cent despite the fact that the region benefited from a very slight increase in workforce jobs, at 8,00o during this period. Critically, however, Wales also benefited from the highest allocations of per capita combined ESF and ERDF allocations of all regions during this period. It may be argued that the level of youth unemployment in Wales is lower than youth unemployment in London during this period due to targeted programmes and higher levels of investments aimed at young people's sustained transition between education and employment inherent in a number of ESF/EDRF funded projects. Conversely, despite strengthening labour market conditions (growth of 100,000 jobs during the period), Local Enterprise Partnerships in London have access to lower levels of EU funding resulting in lower levels of targeted investment in projects which benefit young people as they undergo their transition between education and the labour market. In particular, in terms of growth sectors, there is a higher demand for highly skilled and professional workers in London necessitating the availability of training in higher skills. Here, the alignment between forms and levels of skills training for young people and available job opportunities within distinct local labour market settings is critical. Enabling young people to gain access to forms of skills training and knowledge development relevant to a global knowledge economy is widely regarded as central to more resilient and inclusive 
labour markets (Tomlinson, 2013; European Commission, 2016; EU, 2015; OECD, 2016).

Young people in Wales have gained access to projects funded by the ESF and the targeted YEI with the focus upon 'individual persons rather than structures' (Official Journal of the EU, 2013: 19). Demonstrating this, current ESF-funded projects in Wales include the West Wales and the Valleys European Social Fund Programme ( $\mathfrak{6} 650 \mathrm{~m}$ EU grant at current exchange rate) aimed at effectively supporting people into work and upskilling those people in work but at risk because of a lack of appropriate skills (Rhondda Cynon Taf County Borough Council, 2016).

The contribution of European Funding to co-funded ESF/SFA(Skills Funding Agency) apprenticeships in England is significant. The UK government has proposed that it will create an additional three million apprenticeships by 2020. The current UK government plans to replace the EU funding element for apprenticeships (co-financed ESF/SFA) with a business levy by April 2018. This raises important issues for the sustainability of apprenticeships particularly in regions with weaker economic profiles.

\section{The UK's withdrawal from the EU and the termination of EU funding}

As the evidence above has demonstrated, a large number of UK programmes and projects directed at vulnerable young people in the UK are co-funded by the European Social Fund. When combined with substantial levels of EDRF funding provided for local economic development in poorer areas of the UK the impact of the withdrawal of this funding will be substantial. The House of Lords European Union Committee Report (2017) clearly outlines the legal provisions of Article 50 upon the withdrawal of EU funding. Critically, the European Commission has provided a very clear description of the impact of two options for withdrawal from the EU under Article 50. The first by agreement would set out "the arrangements for the UK's withdrawal in an orderly manner as under the terms of the Vienna Treaty, any right, obligation or legal situation of the parties created through the execution of the treaty prior to its termination". Such issues would include ongoing legal and financial obligations under the Own Resources Decision, the Multiannual Financial Framework, and the Annual Budget. The withdrawal agreement could also include a dispute resolution mechanism, in case of future disagreement. Once the withdrawal agreement enters into force, Article 50(3) TEU makes clear that the EU "Treaties shall cease to apply to the State in question." (House of Lords Select Committee on the European Union, 2017: Brexit and the EU Budget Appendix 3: Advice by the Legal Adviser to the European Union Committee-The UK's obligations under the EU Budget on withdrawal from the EU without a withdrawal agreement: 21)

Crucially this would enable the negotiation of clear transitional arrangements for funding including the retention of specific EU programmes 
or areas of cooperation. In this case, projects and programmes currently funded by the EU would be able to plan for either the eventual withdrawal of funding or continued cooperation and funding opportunities negotiated within the final settlement. In particular the inclusion of a dispute-resolution mechanism in the case of future disagreement would provide some safeguards and security for projects currently funded by the EU for the effective transition from EU co-funding to UK Government/Business co-funded arrangements.

The stark reality for projects currently directed at vulnerable young people in the UK is that all EU funding will cease immediately if no agreement is reached between the UK and the European Commission within the two-year time period. The 'travaux préparatoires' (preparatory work) states that the two-year cut-off was inserted to ensure that the right of a member state to withdraw from the EU was unilateral, rather than dependent on the conclusion of a withdrawal agreement.

The second option is stark: if no agreement is reached within two years, the effect is exactly the same as if a withdrawal agreement had been agreed and entered into force: the EU 'Treaties shall cease to apply to the State in question' (Article 50(3) TEU). The second option allows, therefore, for the most disorderly of withdrawals.'(House of Lords Select Committee on the European Union: Brexit and the EU Budget Appendix 3: 21)

Thus, the approach of the UK Government during the Brexit negotiations is critical to transitional arrangements for EU co-funded projects directed at vulnerable young people in the UK.

\section{Conclusion}

As the evidence above has demonstrated, the impact of the UK's withdrawal from the EU on young people making the transition between education and employment in a post-Brexit UK will be significant. If an agreement is reached, the scope for transitional arrangements and the replacement of EU funding for co-funded projects will significantly mitigate these impacts particularly where specific EU programmes continue after the UK's exit from the European Union. Despite this, the broader implications of the loss of the spatial redistributive capacity of EDRF funding, addressing regional economic and labour market disparities, and ESF funding, directed at alleviating youth poverty and social exclusion through local targeted programmes, are of particular concern. In particular, the loss of EU co-funding of programmes designed to support vulnerable young people as they make the transition between education and employment will be considerable unless the UK government fully replaces this funding. This reassurance will become particularly vital in the event of no agreement being reached with the European Union. The unilateral decision to leave the EU without a negotiated settlement will lead to a disorderly exit from the EU and the immediate withdrawal of European support for UK projects (House 
of Lords, 2017). In light of this the UK government has recently proposed a levy on businesses to ensure that EU co-funded apprenticeship schemes across the UK continue. This proposal is consistent with the current UK government's focus on business-led transformations in employment rules and regulations rather than employment rules, regulations and rights determining the structure of modern business models. Critically this increased emphasis on prioritizing the needs of the market ('modern' economy) and 'modern' business models strongly implies a market-led post-Brexit political economy in the UK if the current government retains power following the General Election on 8 June 2017 (UK Government, 2017). The disproportionate impact of this transformation on the employment conditions of vulnerable young people in the UK is of particular concern as young people aged between 18 and 25 hold more non-standard contracts than any other age group with over one-third of all zero-hours contracts in the UK labour market being held by young people (ONS, 2017). A central concern is the extent to which representatives of vulnerable groups and trade unions will have a voice in the 'Independent review' of employment practices and subsequent changes in employment rights and regulations following the UK's exit from the European Union (UK Government, 2017). Further, the degree to which new forms of co-funding will deliver continuity in providing effective and locally relevant programmes for vulnerable young people is highly contingent upon the development of policy architectures and forms of governance which enable collaborative design, delivery, evaluation and sustainability of local programmes. When combined with societal risks associated with the withdrawal of EU employment rights and protections, educational mobility schemes and transnational apprenticeships, the UK's withdrawal from the EU will herald a period of increased insecurity and vulnerability for a whole generation of young people in the UK. An initial glance through the looking glass into the uncertainties of life in a post-Brexit UK led 71 per cent of young people between the ages of 18 and 24 to vote to remain in the European Union in 2016 (YouGov, 2016). Unlike Lewis Carroll's imagined world in which Alice regards herself as courageous in overcoming the unnerving fantasy figures that threaten her identity and her future (Carroll, 1865), the economic, social and personal challenges currently faced by vulnerable young people in the UK are very real and will be exacerbated in a post-Brexit Europe. The need to develop inclusive and coherent policy architectures, forms of governance and spatially redistributive investment strategies which support locally relevant sustainable programmes for young people within a post-Brexit UK is now an urgent priority of current and future UK governments.

\section{References}

Barca, F. (2009), An Agenda For A Reformed Cohesion Policy. A place-based approach to meeting European Union challenges and expectations. Independent Report prepared at the 
request of Danuta Hübner, Commissioner for Regional Policy, http://www.dps.mef.gov.it/ documentazione/comunicati/2010/report_barca_v0306.pdf [accessed 04.01.2017]

Booth, S., Howarth, C., Persson, M., Ruparel, R. and Swidlicki, P. (2015), What If? The Consequences, Challenges and Opportunities facing Britain outside the EU, London: Open Europe, http://europas-krisen.zdf.de/media/downloads/Brexit/150507-Open-EuropeWhat-If-Report-Final-Digital-Copy.pdf [accessed 3.02.2017]

Carroll, L. (1865), Alice in Wonderland, MacMillan Press. London.

Davis, D. (2016), Britain would be better off out of the EU - and here's why. Conservative Home. http://www.conservativehome.com/platform/2016/o2/david-davis-britain-would-bebetter-off-out-of-the-eu-and-heres-why.html. February 4, 2016 [accessed 03.03.2017]

Dhingra, S., Ottaviano, S., Sampson, T. and Van Reenen, J. (2016), The consequences of Brexit for UK trade and living standards. The London School of Economics and Political Science. Centre for Economic Performance. 1-15

Ebell, M. and Warren, J. (2016), 'The Long-Term Impact of Leaving the EU'. National Institute Economic Review, number 236, May 2016. 121-138

Elliott, I. (June 2016), Poverty and Mental Health: A review to inform the Joseph Rowntree Foundation's Anti-Poverty Strategy. London: Mental Health Foundation. 1110

Ellison, M. (2014), 'No Future to Risk? The impact of economic crises and austerity on the inclusion of young people within distinct European labour market settings'. In: Social Policy Review. Policy Press, Bristol, pp. 155-179

Ellison, M. and Fenger, M. (2013), 'Review article: Social Investment, Protection and Inequality within the New Economy and Politics of Welfare in Europe'. Social Policy and Society, Volume 12, pp. 611-625.

Ellison, M. (2013), Identifying Policy Innovations increasing Labour Market Resilience and Inclusion of Vulnerable Groups. Edinburgh, Queen Margaret University. http://www.inspires-research.eu/userfiles/SCOTLAND\%2oFINAL\%2oREPORT\%2 oFOR\%20WP3\%2oAuthor\%2oM\%2oEllison\%20QMU\%2oEdinburgh\% 20Scotland(2).pdf [accessed 3.02.2017]

Ellison, M. and Van Berkel, R. (2014), 'Introduction, Innovative social and labour market policies in Europe in times of crisis'. International Social Security Review, Vol. 67, 1/2014 $1-10$

European Commission (2000), EU Programme for Peace and Reconciliation in Northern Ireland and the Border Region of Ireland 2000-2004. Operational Programme "Reinforcing Progress towards a Peaceful and Stable Society and Promoting Reconciliation" 1-278, http://ec.europa.eu/regional_policy/archive/country/overmap/ pdf_region/fp2mc_en.pdf [accessed 05.03.2017]

European Commission (2014), 'Guidance on Implementing the Youth Employment Initiative. European Social fund thematic paper'. Directorate-General for Employment, Social Affairs and Inclusion Unit Luxemburg. 1-32., http://www.google.co.uk/url? $\mathrm{sa}=\mathrm{t} \& \mathrm{rct}=\mathrm{j} \& \mathrm{q}=\& \mathrm{esrc}=\mathrm{s} \&$ source $=$ web $\& \mathrm{~cd}=1 \& \mathrm{cad}=\mathrm{rja} \& u a c t=8 \& \mathrm{ved}=\mathrm{oahUKEwiB}$ po-NlYHUAhUGVRoKHcpfAqYQFgguMAA\&url=http\%3A\%2F\%2Fec.europa.eu\%2Fe sf $\% 2$ FBlobServlet $\% 3$ FdocId $\% 3$ D 457\%26langId\% ${ }_{3}$ Den\&usg=AFQjCNELdDs9K5dX-Oy EmhToxyYtMbDVzQ [accessed 04.01.2017]

European Commission (2016), 'A New Skills Agenda For Europe'. Communication From The Commission To The European Parliament, The Council, The European Economic And Social Committee And The Committee Of The Regions. Brussels, 10.6.2016 $\operatorname{Com}(2016) 381$ final. 1-18. http://ec.europa.eu/social/main.jsp?catId=1223\&langId=en [accessed 07.03.2017]

European Commission (2017), EU Expenditure and Revenue, 2014-2020; Data extracted for 2000-2015, http://ec.europa.eu/budget/figures/interactive/index_en.cfm [accessed 9th January, 2017]

Eurostat (2017), Regional Database. http://ec.europa.eu/eurostat/web/regions/overview. Accessed 20 ${ }^{\text {th }}$ March 2017 [accessed 13.03.2017] 
Furlong, A. and Cartmel, F. (2004), Vulnerable Young Men in Fragile Labour Markets, York: Joseph Rowntree Foundation. UK. 1-48

Gardiner, L. (2014), 'Zero-Hours Contracts: The latest figures and analysis'. The Resolution Foundation, analysis and action on living standards. London. Published on 30 April $2014 \mathrm{http}$ //www.resolutionfoundation.org/publications/zero-hours-contracts-the-latestfigures-and-analysis/ [accessed 4.1.2017]

House of Lords Select Committee on Digital Skills (2015), Make or Break: The UK's Digital Future. HL Paper 111. Published by the Authority of the House of Lords. London : The Stationery Office Limited 1-144. https://www.publications. parliament.uk/pa/ld201415/ldselect/lddigital/111/111.pdf [accessed 14.04.2017]

House Of Lords European Union Committee (2017), 15th Report of Session 2016-17 HL Paper 125 Brexit and the EU budget. $4^{\text {th }}$ March, 2017. 1-65 https://www.publications.parliament. $\mathrm{uk} / \mathrm{pa} / \mathrm{ld} 201617 / \mathrm{ldselect} / \mathrm{ldeucom} / 125 / 125 . \mathrm{pdf}$ [accessed 12.03.2017]

Hunt, T., Lavery S., Vittery, W. and Berry C. (2016), 'UK Regions and European Structural Investment Funds'. Sheffield Political Economy Research Unit. SPERI British Political Economy Brief No. 24. The University of Sheffield. 1-15, http://speri.dept.shef. ac.uk/wp-content/uploads/2016/05/Brief24-UK-regions-and-European-structural-andinvestment-funds.pdf [accessed 03.04.2017]

ILO, (2016), Global Employment Trends for Youth 2016, Geneva: ILO. 1-59 http://www. ilo.org/wcmsp5/groups/public/—dgreports/—dcomm/—publ/documents/publication/ wcms_513739.pdf [accessed on 18.02.2017]

IPPR (2017), 'New Skills at Work', http://www.ippr.org/major-programmes/new-skills-at-work [accessed 17.05.2017]

Irwin, G. (2015), 'BREXIT:the impact on the UK and the EU, June 2015', Global Counsel. Report prepared by Chief Economist of the Global Counsel, Dr Gregor Irwin, https://www.global-counsel.co.uk/sites/default/files/special-reports/downloads/Global\% 20Counsel_Impact_of_Brexit.pdf

Lindsay, C. and Houston, D. (2011), Fit for purpose? Welfare reform and challenges for health and labour market policy in the UK, Environment and Planning, 43, 703721.

MacDonald, R. (2011), 'Youth transitions, unemployment and underemployment: Plus ca change, plus c'est la me^me chose?' Journal of Sociology 47(4): 427444.

MacGowan, A. (Narrator) (2017, May 10 $\left.{ }^{\text {th }}\right)$, Angela MacGowan, Northern Ireland Director of the CBI: Radio Four Today Programme 10/5/2017: Ireland and its relationship with Britain, 8.30 am.. John Humphrys (Presenter). Jamie Angus; (Producer). http://www.bbc.co.uk/programmes/bo8p5l73

McIver, I. and Wakefield, S. (2016), SPICe Briefing European Union Funding in Scotland, 2014-2020. 7th November 2016. 16/89. Scottish Parliament Publication. Edinburgh 1-30. http://www.parliament.scot/ResearchBriefingsAndFactsheets/S5/SB_16-89_European_ Union_Funding_in_Scotland_2014-2020.pdf [accessed on 16.01.2017]

Office for National Statistics (2015), NOMIS: Official labour market statistics web pages. https://www.nomisweb.co.uk/ [accessed 08.04.2017]

North East Local Enterprise Partnership (2017), http://www.nelep.co.uk/ [accessed on 26.02.2017]

OECD (2013), Crisis squeezes income and puts pressure on inequality and poverty, s.l.: OECD. 1-8, http://www.oecd.org/els/soc/OECD2013-Inequality-and-Poverty-8p.pdf [accessed 19.01.2017]

OECD (2016), Skills Matter: Further Results from the Survey of Adult Skills, OECD Publishing, Paris. DOI: http://dx.doi.org/10.1787/9789264258051-en. [accessed o6.02.2017]

Office for National Statistics (2017), Labour Force Survey: regional labour market statistics. [Online] Available at: http://www.ons.gov.uk/ons/rel/subnational-labour/regional-labourmarket-statistics/january-2014/stb-regional-labour-market-january-2014.html [accessed 06.04.2017] 
Office for National Statistics. (2017), Contracts that do not guarantee a minimum number of hours: May 2017, https://www.ons.gov.uk/employmentandlabourmarket/peopleinwork/ earningsandworkinghours/articles/contractsthatdonotguaranteeaminimumnumberof hours/latest [accessed 20.01.2017]

Ottaviano, G., Pessoa, J., Sampson, T. and Van Reenen, J. (2014), 'The Costs and Benefits of Leaving the EU', Centre for Economic Performance Policy Analysis. http://cep.lse. ac.uk/pubs/download/pao16_tech.pdf [accessed 12.13.2017]

Otto, A. and Taylor-Gooby, P. (2014), National report on the labour market position of vulnerable groups in the United Kingdom. Kent: University of Kent. http://www.inspires-research. eu/userfiles/D2_1\%20National\%2oreport\%20UK(1).pdf [accessed 14.02.2017]

Oxford Economics (2016), 'Assessing the Economic Implications of Brexit', Oxford Economics. London. 1-5 http://www.oxfordeconomics.com/brexit/executive-summary [accessed on 20.03.2017]

Rhondda Cynon Taf County Borough Council (2016), Finance and Performance Scrutiny Committee. Municipal Year 2015-2016. http://www.rctcbc.gov.uk/EN/Council/ CouncillorsCommitteesandMeetings/Meetings/FinanceandPerformanceScrutinyCommi ttee/2015/10/07/Reports/Item3EuropeanUnionfundingprogrammesinWales2014to2020. pdf [accessed 27.04.2017]

Roberts, S. (2011), 'Beyond 'NEET' and 'tidy' pathways: considering the 'missing middle' of youth transition studies', in Journal of Youth Studies, 14, 1: 21-39.

Schraad-Tischler, D. (2015), Social Justice in the EU 2015 -Index. Social Improvement Monitor. Bertelsmann Siftung 2015.1-178. https://www.social-inclusion-monitor.eu/uploads/tx_ itao_download/Studie_NW_Social-Justice-in-the-EU-Index-Report-2015_2015_01.pdf. [accessed 07.03.2017]

Scottish Government (2015a), Scotland's Action Plan for EU Engagement. The Scottish Government. Edinburgh. 1-14. March 27 ${ }^{\text {th }}$, 2015, http://www.gov.scot/Resource/ 0047/00473826.pdf. [accessed 20.02.2017]

Scottish Government (2015b), European Parliament Engagement Report on Skills Policies for Fighting Youth Unemployment. The Scottish Government, Edinburgh. http://www.gov.scot/Topics/International/Europe/Case-Studies/YouthUnemployment [accessed 19.02.2017]

Scotland Europa (2017), Supporting early Scottish Engagement in the EU Smart Cities Initiative. https://portal.scotlandeuropa.com/case-studies/4 [accessed on 07.02.2017 ]

South West Greenerin.org.uk (2017), 'European Union Funding Profile: South West of England \& Gibraltar'.1-9. http://www.swgreenerin.org.uk/wp-content/uploads/ 2016/04/Briefing-EU-Funding-to-the-South-West-of-England.pdf [accessed 02.03. 2017]

The Scottish Government (2015), Working for Growth a Policy Refresh http://www.gov.scot/Publications/2012/09/5609/2 [accessed 10.01.2017]

The Northern Ireland Government, Department of Economy (2016), Northern Ireland European Social Fund programme 2014-2020. Northern Ireland Government. https://www.economy-ni.gov.uk/esf [accessed 20.03.2017]

The Prince's Trust Macquarie (2014), Youth Index 2014, London: The Prince's Trust. [Online] Available at: https://www.princes-trust.org.uk/help-for-young-people/ news-views/youth-index-2014 [accessed on 06.02.2017]

The Welsh Government (2017), European Territorial Cooperation Programmes. http://gov.wales/funding/eu-funds/european-cooperation/?lang=en [accessed on 14.03.2017]

Thompson, R. (2011), Individualisation and social exclusion: The case of young people not in education, employment or training. Oxford Review of Education, 37 (6): 785-802.

Tinson, A., Ayrton, C., Barker, K., Born, T., Aldridge, H. and Kenway, P. (2016), Monitoring poverty and social exclusion 2016 (MPSE) $7^{\text {th }}$ December, 2016. 1-148 https://www.jrf. org.uk/report/monitoring-poverty-and-social-exclusion-2016 [accessed 03.03.2017]

Tomlinson, S. (2013), 'Social Justice and Lower Attainers in a Global Knowledge Economy'. Social Inclusion, 1(2), 102-112. 
UK Government (2017), White Paper on the United Kingdom's exit from and new partnership with the European Union. https://www.gov.uk/government/ publications/the-united-kingdoms-exit-from-and-new-partnership-with-the-europeanunion-white-paper/the-united-kingdoms-exit-from-and-new-partnership-with-theeuropean-union-2 [accessed on 16.05.2017]

YouGov (2016), 'How Britain Voted' https://yougov.co.uk/news/2016/o6/27/how-britain-voted/ [accessed 8.1.2017] 